\title{
Mental health and suicidal behaviors in adolescents from a Portuguese island
}

\author{
Saúde mental e comportamentos da esfera suicidária dos adolescentes duma regiáo insular \\ portuguesa \\ Salud mental y comportamientos de la esfera suicida de los adolescentes de una región \\ insular portuguesa
}

Márcia Fernanda Bettencourt Vieira Neves*; José Carlos Santos**

\begin{abstract}
Background: Adolescent suicidal behaviors are a public health priority.

Objectives: Suicidal behavior is an understudied field in the Azores, and the few existing research studies with Portuguese adolescents only include young people from Mainland Portugal. This study aims at analyzing the adolescent student population from this island region so as to describe the current situation and plan community intervention projects in this area to meet the identified needs.

Methodology: This is a non-experimental, quantitative and descriptive-correlational study with the purpose of describing phenomena and finding associations between variables.

Results: The results showed that $17.9 \%$ of the 484 sampled adolescents reported self-harm behaviors, with $12.7 \%$ reporting self-cutting and 5.2\% medication overdose or ingestion of toxic substances. Around 15.5\% of the adolescents reported suicidal ideation. Additionally, they showed high levels of depressive symptoms (19.9\%), ranging from moderate (12\%) to severe (7.9\%). Conclusion: Adolescents had more self-harm behaviors, more severe depressive symptoms, a lower self-concept and fewer coping strategies than similar populations in mainland Portugal.
\end{abstract}

Keywords: mental health; adolescent; self-injurious behavior; epidemiology; school

\section{Resumo}

Enquadramento: Os comportamentos suicidários nos adolescentes representam uma área prioritária em termos de saúde pública.

Objetivos: Os comportamentos suicidários são uma área pouco estudada na região dos Açores, e os poucos estudos existentes com adolescentes nesta área incluem jovens de Portugal Continental. Pretende-se com este trabalho estudar a população adolescente estudante da região insular de modo a conhecer a realidade atual e planear projetos de intervenção comunitária nesse âmbito, por forma a dar resposta às necessidades identificadas.

Metodologia: Estudo não experimental, quantitativo e descritivo-correlacional uma vez que serve para descrever fenómenos e encontrar relações entre variáveis.

Resultados: Amostra de 484 estudantes, mostram taxas de comportamentos autolesivos totalizando $17,9 \%$, sendo $12,7 \%$ por cortes deliberados e 5,2\% por toma de comprimidos ou tóxicos. Cerca de 15,5\% apresentam ideação suicida. Apresentam ainda níveis elevados de sintomatologia depressiva (19,9\%), sendo $12 \%$ considerada moderada e 7,9\% severa.

Conclusão: Os adolescentes apresentam mais comportamentos autolesivos, maior sintomatologia depressiva, menor autoconceito e menor coping que populações semelhantes no continente.

Palavras-chave: saúde mental; adolescente; comportamento autodestrutivo; epidemiologia; escola

\footnotetext{
* MSc., Specialist Nurse, Master in Mental Health Nursing, USIP-Healthcare Center of Madalena Estrada Longitudinal 9950-322 Madalena Pico, Açores, Portugal [a21125002@esenfc.pt]. Address for correspondence: Estrada Nova $\mathrm{n}^{0} 5$ Criação-Velha 9950-231, Madalena. Contribution to the article: conduction of research study and article writing.

* PhD, Coordinating Professor, Nursing School of Coimbra, 3045-444, Coimbra, Portugal [jcsantos@esenfc.pt].Contribution to the article: supervision of research study and article writing.
}

\section{Resumen}

Marco contextual: Los comportamientos suicidas en los adolescentes representan un área prioritaria de la salud pública. Objetivos: Dadas las lagunas existentes en los estudios de investigación en el área de los comportamientos suicidas en Las Azores y teniendo en cuenta que los escasos estudios en esta área con adolescentes portugueses incluyen jóvenes de Portugal Continental, se pretende, con este trabajo, estudiar la población adolescente estudiante de la región insular con el objetivo de conocer la realidad actual y planear proyectos de intervención comunitaria en ese ámbito para dar respuesta a las necesidades identificadas.

Metodología: Estudio no experimental, cuantitativo y descriptivo-correlacional, ya que sirve para describir fenómenos y encontrar relaciones entre variables

Resultados: Una muestra de 484 estudiantes presenta una tasa de comportamientos autolesivos del 17,9\%, el 12,7\% se debe a cortes deliberados y el 5,2 \% a la toma de comprimidos o tóxicos. Cerca del 15,5\% presenta ideas suicidas. Además, presenta niveles elevados de sintomatología depresiva el 19,9 $\%$, del cual el $12 \%$ se considera moderada y el 7,9\% severa. Conclusión: Los adolescentes presentan más comportamientos autolesivos, mayor sintomatología depresiva, menor autoconcepto y menor coping que las poblaciones semejantes en el continente.

Palabras clave: salud mental; adolescente; comportamiento autodestructivo; epidemiología; escuela

Received for publication: 01.06 .15

Accepted for publication: 13.05 .16 


\section{Introduction}

Adolescence is characterized by several physical and psychological transformations, which may lead to irreverent behaviors and to the questioning of the children's models and standards which are necessary to the growth process (Ferreira \& Nelas, 2006). Thus, young people may find it hard to cope with the many changes happening all at once and need help to overcome the events inherent to this process (Sampaio, 2006).

Suicidal behaviors are a serious and complex social problem. According to Saraiva (2006), these behaviors serve as a way to erase the anguish of psychological pain in the absence of other psychological mechanisms to deal with conflicts, failure and loss. As such, these behaviors are always used in emergency situations, and require a set of interventions to assess the problem and the required approach, i.e. early identification, referral and treatment of young people at risk of suicide.

This study is relevant because, although rare in Portugal, suicide is the second leading cause of death among young people aged between 15 and 24 years, following road traffic accidents (Sampaio, 2006). In addition, suicidal behaviors are relatively common in this age group. The Azores has a suicide rate of more than 25 suicides per 100,000 inhabitants, which is the highest rate in Portugal for this age group (Carvalho \& Mateus, 2016).

Therefore, the identification of individuals at risk is important for the strategies to be reviewed. Taking into account that the few studies on suicidal behaviors among Portuguese adolescents target young people from Mainland Portugal, this study aims at analyzing some aspects of the mental health of adolescents, particularly adolescents from Pico Island (Azores):well-being, self-concept, depression, coping and suicidal behaviors. It also seeks to understand the associations between these variables. This study aimed to analyze the adolescent student population of Pico Island so as to describe the current situation and plan community intervention projects in this area to meet the identified needs.

\section{Background}

\section{Depression}

Adolescence is a phase characterized by changes which create an ambivalence of feelings and mental health transformations and may lead to mood disorders. The number of adolescents with depressive episodes has significantly increased, to the extent that it is now an actual public health issue (Thapar, Collishaw, Pine, \& Thapar, 2012). The World Health Organization (World Health Organization \& International Association for Suicide Prevention [WHO], 2016 report that, in Europe, depression affects around $4.0 \%$ and $9.0 \%$ of young people aged 12-17 years and over 18 years, respectively. Santos, Erse, Façanha, Marques, and Simões (2014), in a study with a sample of 2,354 adolescents from the Center region, showed that $15.7 \%$ of the adolescents had moderate or severe depressive symptoms, with a higher incidence among female adolescents.

Depression is also an important predictor of suicidal ideation, which indicates that adolescents with depression may develop suicidal thoughts (Borges, Werlang, \& Copatti, 2008). Thus, in order to minimize the risk of depression, adolescents require a meaningful social support network, including the family, the group of friends and the school (Cordeiro, Claudino, \& Arriaga, 2006).

\section{Suicidal behaviors in adolescence}

Adolescence is a phase of intense transformations and occasional conflicts, during which adolescents may use aggressive, impulsive or even suicidal behaviors as a solution for their problems (Borges et al., 2008). In this period, mental suffering is relatively common (Saraiva, 2006). Studies have identified several risk factors, which Santos et al. (2014) divided into three categories: predisposing factors, which can be present at birth and allow identifying risk groups (genetic or biological factors, personality traits); short-term factors, which develop during adolescence and allow predicting the likelihood of committing suicide (mental disorder, situational factors); and precipitating factors, which are related to life events or the possibility of access to the methods of committing suicide that allow a more immediate assessment of the risk of suicide.

Madge et al. (2011) found a strong association between increased severity of self-harm history and higher levels of depression, anxiety, impulsivity and lower levels of self-esteem, as well as stressful life events in areas of the adolescents' lives. With regard to psychological characteristics and stressful life events, the authors found similarities between adolescents 
only with thoughts of self-harm and those with a single self-harm episode. The CASE - Child \& Adolescent Self-harm in Europe study (Madge et al., 2011) reported a high prevalence of self-harm behaviors and thoughts, with $13.5 \%$ of female adolescents and $4.3 \%$ of male adolescents reporting an episode in their life. If untreated, self-harm behavior, which is the strongest suicide risk factor (WHO, 2012), can lead to suicide (Thapar et al., 2012).

Suicidal ideation has a prevalence rate of $15 \%$ to 25\% among adolescents (Bridge, Goldstein, \& Brent, 2006). It is considered as a major risk factor for suicide, although suicidal thoughts do not always precede the act (Park et al., 2010). In Portugal, in a study conducted in the Lisbon region, $7.3 \%$ of the 1,713 sampled adolescents reported having had at least one self-harm episode (Guerreiro, Sampaio, Figueira, \& Madge, 2015).

Adolescents with suicidal behaviors have more health problems, more escape, aggressive and pre-delinquent behaviors and higher substance use than adolescents in general. They also have a negative self-image and more school failure.

According to the WHO (2012), global suicide rates are expected to increase until 2020. Suicide is among the five leading causes of death in the 15 to 19 age group, and the second leading cause of death in the 15 to 24 age group.

Since schools are the ideal, logical and natural place to develop suicide prevention programs for young people (Pompili, Innanorati, Girardi, Tatarelli, \& Lester, 2011), data were collected in schools.

\section{Research questions}

What are the levels of well-being, self-concept, coping and depression among the adolescents from the Pico island? What are the levels of suicidal behaviors among the adolescents from the Pico island?

\section{Research hypotheses}

H1 - Girls are more vulnerable to suicidal behaviors than boys, particularly in terms of depressive symptoms, coping, self-concept and psychological well-being; H2 - Vulnerability to suicidal behaviors increases with age, particularly in terms of depressive symptoms, coping, self-concept and psychological well-being; $\mathrm{H} 3$ - Adolescents with a history of suicidal ideation have more depressive symptoms.
In this study, the presence of high depressive symptoms and low psychological well-being, coping and self-concept confirmed vulnerability.

\section{Methodology}

Taking into account the study objectives, and since we aimed at analyzing and identifying associations between variables with the purpose of generalizing the results obtained from a specific sample of the population, we conducted an exploratory, non-experimental, quantitative and descriptivecorrelational study. We considered the adolescents' mental health as a variable, which was obtained through the following indicators: well-being, self-concept, depression, coping, and type of suicidal behavior. The attribute variables were age, gender, and education.

The target population was composed of all students from three schools in Pico attending the $7^{\text {th }}$ to $12^{\text {th }}$ grade. The application of this criterion resulted in a population of 787 students, aged between 11 and 25 years. However, since some legal guardians did not sign the informed consent for participation in the study, the final sample was composed of 484 students. Data were collected through a questionnaire on the participants' sociodemographic characteristics (age, gender, and grade) and on the type and frequency of suicidal behaviors. It also included some measurement instruments which had already been validated for the Portuguese reality: the WHO-Five Well-being Index, which measures the current mental well-being; the Toulousaine Coping Scale (Tap, Costa, \& Alves, 2005), which analyzes how adolescents cope with difficult situations; the Piers-Harris Children`s Self-concept Scale (PHCSCS-2; Veiga, 2006), which is a multidimensional self-concept scale; and the Beck Depression Inventory (Martins, 2000), which allows respondents to describe how they have been feeling for the past 2 weeks. The questionnaire used in this study was based on the +Contigo Project (Santos et al., 2014). Each student completed the questionnaire individually in the classroom (during the course of Civic Education) for approximately 30 minutes. Students were informed about the purpose of the study and confidentiality was ensured. Data were collected over a period of approximately 2 months, between March and April 2013. 
The Executive Directors of the schools in Pico Island were contacted and authorized the application of the questionnaires to their $7^{\text {th }}$ - to $12^{\text {th }}$-grade students. The class directors received the informed consent forms to be delivered to the students' legal guardians prior to questionnaire application. The consent form included a description of the study purpose and ensured data anonymity and confidentiality.

We used the software Statistical Package for the Social Sciences (SPSS), version 20.0, to process and analyze the data. Descriptive and inferential statistics were used.

First, descriptive statistics were used, namely absolute $(n)$ and percentage (\%) frequencies, mean, and standard deviation. Reliability was obtained through the internal consistency coefficient (Cronbach's alpha) which allows estimating the extent to which each scale item equally measures the same concept. The scales showed excellent Cronbach's alpha values: .89 for the coping and self-concept scales, and .93 for the depression scale. We confirmed the normal distribution of the population using the Kolmogorov-Smirnov test. We used parametric tests after confirming compliance with the following criteria: a sample composed of more than 30 subjects; the values of one variable are measured on an interval or ratio scale; the dependent variable has a normal distribution; and homogeneity of variance. In addition to these tests, we also used Pearson's correlation coefficient to measure the associations between the Piers-Harris Children's Self-concept Scale (PHCSCS-2), the Beck Depression Inventory and the Toulousaine Coping Scale. We should note that, for the acceptance or rejection of simple scale effects, we considered .05 as the significance level $(p>.05=$ non-significant; $p<.05=$ significant; $p<.01=$ very significant $)$.

All ethical procedures were followed, particularly the request for authorization from the Educational Services Managers and the schools to apply the questionnaires, and the informed consent signed by the students' legal guardians..

\section{Results}

The sample was composed of both female (56.6\%) and male (43.4\%) students with a mean age of 15.10 years.

Table 1 shows that approximately $20 \%$ of the adolescents have moderate and severe depression. It also shows scores of 21.35 for well-being, 39.31 for self-concept, and 147.42 for coping.

Table 1

Sample characterization regarding the mean scores for well-being, self-concept and coping, and percentage of depressive symptoms

\begin{tabular}{lcccc}
\hline Mental Health Variables & & SD & Min & Max \\
\hline Well-being Index (mean) & 21.35 & 4.33 & 7.00 & 30.00 \\
Self-concept (mean) & 39.31 & 10.10 & 6.00 & 60.00 \\
Coping (mean) & 147.42 & 21.73 & 51.00 & 224.00 \\
No depression(\%) & 63.6 & & & \\
Mild depression (\%) & 16.3 & & \\
Moderate depression (\%) & 12.0 & & & \\
Severe depression (\%) & 7.9 & & & \\
\hline
\end{tabular}

According to Table 2, when analyzing each behavior individually, we found a high percentage of alcohol consumption and self-harm behaviors, with $12.7 \%$

reporting self-cutting and 5.2\% medication overdose or ingestion of toxic substances. Boys had more risk behaviors and drank more alcohol than girls. 
Table 2

Sample characterization regarding the frequency of suicidal behaviors

\begin{tabular}{lcccc}
\hline Dimensions & \multicolumn{2}{c}{ Total } & \multicolumn{2}{c}{$\begin{array}{c}\text { Gender } \\
\text { (relative frequencies) }\end{array}$} \\
\hline \multirow{3}{*}{ Suicidal ideation } & Never & At least once & Male & Female \\
\cline { 2 - 5 } Death wish & 80.2 & 19.8 & 21.4 & 19.4 \\
Risk behaviors & 78.6 & 22.4 & 20.5 & 22.3 \\
Alcohol consumption & 77.6 & 22.4 & 41 & 23.1 \\
Self-cutting & 64.6 & 35.4 & 44.5 & 28.7 \\
Medication or toxic substances & 87.3 & 12.7 & 12.4 & 13.2 \\
\hline
\end{tabular}

Table 3 shows that, in terms of the association between the age and well-being variables, the levels of wellbeing worsen with age, whereas self-concept slightly increases with age. No statistically significant changes related to age were found in coping and depressive symptoms. In addition, higher levels of well-being are

related to higher levels of coping and self-concept and fewer depressive symptoms. Moreover, the higher the levels of coping, the higher the levels of self-concept and well-being, and the higher the levels of self-concept, the higher the levels of coping and well-being, and fewer depressive symptoms.

Table 3

Pearson's correlation test for the analyzed variables $(r)$

\begin{tabular}{lccccc}
\hline & Age & Well-being & Coping & Self-concept & Depressive symptoms \\
\hline Age & 1 & $-.14^{* *}$ & -.06 & -.02 & -.00 \\
Well-being & $-.14^{* *}$ & 1 & $.28^{* *}$ & $-.43^{* *}$ & $.49^{* *}$ \\
Coping & -.06 & $.28^{* *}$ & 1 & $.10^{*}$ & .07 \\
Self-concept & $.10^{*}$ & $.43^{* *}$ & $.10^{*}$ & 1 & $-.60^{* *}$ \\
Depressive symptoms & -.00 & $-.49^{* *}$ & .07 & $-.60^{* *}$ & 1 \\
\hline
\end{tabular}

With regard to gender, the Student's t-test found no significant difference in the analyzed variables according to gender.

Table 4

\section{Suicidal ideation and depressive symptoms}

\begin{tabular}{lcccc}
\hline Suicidal ideation & $\%$ & Depressive symptoms & $\mathrm{f}$ & $p$ \\
\hline Never & 79.5 & 9.63 & & \\
\hline Once or twice & 15.5 & 30.95 & & $.000^{* *}$ \\
\hline More than twice & 4.3 & 18.54 & & \\
\hline
\end{tabular}

The Tukey's post-hoc test showed differences between the mean scores for the three types of frequencies: a higher difference in the frequency of depressive symptoms among the adolescents who reported having had suicidal ideation once or twice, followed by those who reported having had it more than twice and, finally, by those who had never had these thoughts.
Table 4 shows differences between the mean scores for depressive symptoms and the frequency of suicidal ideation.

\section{Discussion}

The questionnaire had a response rate of $61.8 \%$, which allows for the characterization of the adolescent population. This response rate is explained by the fact that the remaining students' legal guardians did not sign the informed consent in due time. The non-authorization from the legal guardians may relate to 
their concern about the topic under study, as they believe that they are protecting their children against unpleasant issues, which may induce such behaviors. Taking into account the various misconceptions about suicide, such as the idea that talking about suicide can lead to suicidal acts, some legal guardians may feel anxious or underprepared to address this topic. This emphasizes the need for information and training so as to improve their competences and reduce the myths about suicidal behaviors.

These results do not support the first hypothesis since no significant gender differences were found. These data do not confirm previous studies which found that girls are more vulnerable (Avenevoli, Swendsen, Burstein, \& Merikangas, 2015). The geographical characteristics may justify this homogeneity, which is also partially observed with age. For this reason, we confirmed to some extent the second hypothesis in what concerns well-being and self-concept, which decrease slightly with age, but we were not able to confirm the hypothesis for depressive symptoms, which do not increase with age, in opposition to what is reported in previous studies (Avenevoli et al., 2015), and for coping, which shows a slight increase. The results support the third hypothesis because adolescents with suicidal ideation have higher scores of depressive symptoms than other adolescents, which is in line with previous studies where depression is a risk factor for suicidal ideation (Hawton, Saunders, \& O'Connor, 2012)

A comparative analysis between the results of our study and the results of the + Contigo Project (Santos et al., 2014) on mental health shows that young people from Mainland Portugal have better mental health indicators than young people from the Azores in terms of depressive symptoms, self-concept, and coping. The difference in depressive symptoms, particularly in moderate and severe symptoms, should be noted: $15.7 \%$ for the Centre region and 19.9\% for the Azores. Additionally, the percentage of young people who report self-cutting or having taken medication or ingested toxic substances (17.9\%) is significantly higher than the percentage found in the Lisbon region (7.3\%; Guerreiro et al., 2015), which emphasizes the risks for depression and suicidal behaviors in adulthood. We also observed a gender homogeneity concerning suicidal behaviors, which is not consistent with previous studies conducted in the
Mainland where girls had three times more suicidal behaviors than boys (Guerreiro et al., 2015). However, boys had a clearly higher level of alcohol consumption and more risk behaviors.

In turn, depression can be a predictor of suicidal ideation and allows predicting psychosocial distress in adolescents, which can be a symptom of vulnerability among this age group (Thapar et al., 2012). According to Santos et al. (2014), self-harm behaviors can be used to mitigate emotional pain, stress or anxiety. Research studies report a strong association between a self-harm history and higher levels of depression, anxiety, impulsivity and lower levels of self-esteem, as well as stressful life events in the different domains of the adolescents' lives.

Depressive symptoms may relate to the type of environment. In smaller communities, such as the Pico Island, the adolescents' requests for help are sometimes masked by the shame of being recognized and by the fear of having their history disclosed to those people who are closest to them.

In comparison to the population from the Centre region, Azorean young people have less problem-solving skills (coping): 155.04 in the Center region (Santos et al., 2014) versus 147.42 in the Azores. This dimension can partially explain the high percentage of self-harm behaviors, given the protective effect of adequate coping strategies (Guerreiro et al., 2015). Self-concept, although slightly lower in the Azores, is not significantly different from the results obtained in the Center region (Santos et al., 2014).

Based on the above-mentioned results (Santos et al., 2014), it should be noted that Azorean young people have higher levels of well-being than those from the Mainland. This can be explained by their geographical location because living in an island may allow for closer positive relationships across the different contexts (family, environment and school; Poletto \& Koller, 2009), which is considered essential key factor for well-being. In addition, living in a smaller community, where everyone knows each other, facilitates the adolescents' inclusion, participation in activities and in the community (sports team, parish youth groups, brass bands, among others), promoting a strong sense of belonging and well-being.

A higher response rate would have allowed for more solid findings; as such, we consider it to be a limitation of this study. 


\section{Conclusion}

The shortage of mental health professionals, the geographical asymmetry issues inherent to an island setting, and the high percentage of self-harm behaviors are factors that emphasize the need for preventive interventions in mental health. Therefore, the school is a key place for identification, referral and intervention in situations of mental health disorders. Thus, we suggest the following interventions: contacting the school health teams in the three municipalities, and planning initiatives for parents and teachers to help demystify mental health and psychiatry, explain and identify risk behaviors; encouraging the timely cooperation between the hospital mental health team and the primary health care team; promoting self-concept, coping, and well-being, as well as treating depressive symptoms among adolescents; raising the awareness of the adolescent population about the harmful effects of alcohol and drug use; and disseminating information among the adolescent population concerning warning signs and seeking help.

\section{References}

Avenevoli, S., Swendsen, J., He, J., Burstein, M., \& Merikangas, K. (2015). Major depression in the National Comorbidity Survey-Adolescent Supplement: Prevalence, correlates and treatment. Journal of the American Academy of Child \& Adolescent Psychiatry, 54(1), 37-44. doi: 10.1016/j. jaac.2014.10.010

Borges, V., Werlang, B., \& Copatti, M. (2008). Ideação suicida em adolescentes de 13 a 17 anos. Barbarói, 28, 109-123.

Bridge, J. A., Goldstein, T. R., \& Brent, D. A. (2006). Adolescent suicide and suicidal behavior. Journal of Child Psychiatry, 47(3/4), 372-394. doi:10.1111/j.1469-7610.2006.01615.x

Carvalho, A. A., \& Mateus, P. (2016). Portugal: Saúde Mental em números: Programa Nacional para a Saúde Mental. Lisboa, Portugal: Direcção-Geral da Saúde.

Cordeiro, R., Claudino, J., \& Arriaga, M. (2006). Depressão e suporte social em adolescentes e jovens adultos. Revista Iberoamericana de Educación, 39(6), 1-10.

Ferreira, M., \& Nelas, P. B. (2006). Adolescências... Adolescentes.... Millenium, 32, 141-162. Retrieved from http:/hdl.handle. net/10400.19/409

Guerreiro, D., Cruz, D., Frasquilho, D., Santos, J., Figueira, L., \& Sampaio, D. (2013). Association between deliberate selfharm and coping in adolescents: A critical review of the Last
10 Years. Archives of Suicide Research, 17(2), 91-105. doi: 10.1080/13811118.2013.776439

Guerreiro, D., Sampaio, D., Figueira, M., \& Madge, N. (2015). Selfharm in adolescents: A self-report survey in schools from Lisbon, Portugal. Archives of Suicide Research. Advanced online publication. doi: 10.1080/13811118.2015.1004480

Hawton, K., Saunders, K., \& O'Connor, R. (2012). Self-harm and suicide in adolescents. Lancet, 379(9834), 2373-2382. doi: 10.1016/S0140-6736(12)60322-5

Madge, N., Hawton, K., Mcmahon, E. M., Corcoran, P., Leo, D. D., Wilde, E. J., . . A Aresman, E. (2011). Psychological characteristics, stressful life events and deliberate self-harm: Findings from the Child \& Adolescent Self-harm in Europe (CASE) study. European Child Adolescent Psychiatry, 20(10), 499-508. doi: 10.1007/s00787-011-0210-4

Martins, A. M. (2000). As manifestações clínicas da depressão na adolescência (Dissertação de mestrado). Retrieved from http://hdl.handle.net/10216/10115

Park, Y. J., Ryu, H., Han, K. S., Kwon, J. H., Kim, H. K., Kang, H. C., ... Shin, H. (2010). Anger, anger expression, and suicidal ideation in Korean adolescents. Archives of Psychiatric Nursing, 24(3), 168-177. doi: 10.1016/j.apnu.2009.04.004

Poletto, M., \& Koller, S. H. (2009). Resiliência: Uma perspectiva conceitual e histórica. In D. D. Aglio, S. H. Koller \& M. Yunes (Eds.), Resiliencia e psicologia positiva: Interfaces do risco à proteção (pp. 19-44). São Paulo, Brasil: Casa do Psicólogo.

Pompili, M., Innanorati, M., Girardi, P., Tatarelli, R., \& Lester D. (2011). Evidence-based interventions for preventing suicide in youths. In M. Pompili \& R. Tatarelli (Eds.), Evidencebased practice in suicidology: A source book (pp. 171-210). Canada: Hogrefe \& Huber Publishers.

Sampaio, D. (2006). Lavrar o mar: Um novo olhar sobre o relacionamento entre pais e filhos. Lisboa, Portugal: Editorial Caminho.

Santos, J., Erse, M., Façanha, J., Marques, L., \& Simões, R. (2014). +Contigo: Promoção de saúde mental e prevenção de comportamentos suicidários na comunidade educativa. Coimbra, Portugal: Escola Superior de Enfermagem de Coimbra.

Saraiva, C. B. (2006). Psicopatologia e prática clínica. In B. Peixoto, C. B. Saraiva \& D. Sampaio (Coords.), Comportamentos suicidários em Portugal (pp 275-300). Coimbra, Portugal: Sociedade Portuguesa de Suicidologia.

Tap, P., Costa, E., \& Alves, M. (2005). Escala Toulousiana de Coping (ETC): Estudo de adaptação à população portuguesa. Psicologia, Saúde e Doenças, 6(1), 47-56.

Thapar, A., Collishaw, S., Pine, D., \& Thapar, A. K. (2012). Depression in adolescence. The Lancet, 379(9820), 10561067. doi: 10.1016/S0140-6736(11)60871-4

Veiga, F. (2006). Uma nova versão da escala de autoconceito PiersHarris Children `s Self-concept Scale (PHCSCS-2). Psicologia e Educação, 5(1), 39-48. 
World Health Organization, \& International Association for Suicide Prevention. (2016). World Suicide Prevention Day:
10 September, 2012. Retrieved from http://www.iasp.info/ wspd/index.php 